\title{
What is the role of the conservative intervention in the treatment of a torn anterior cruciate ligament?
}

\author{
Ön çapraz bağ yırtılmasının tedavisinde konservatif girişimin rolü nedir?
}

\author{
O. Şahap Atik, MD \\ Department of Orthopedics and Traumatology, Medical Faculty of Gazi University, Ankara, Turkey
}

\begin{abstract}
Anterior cruciate ligament (ACL) injuries are common and the economic burden of these injuries is high. However, the optimal management of a torn ACL of the knee is still controversial. Anterior cruciate ligament surgery is not suitable for all patients; there are some indications for nonsurgical treatment with a strict neuromuscular rehabilitation program in selected patients. Neuromuscular rehabilitation is also necessary prior to ACL reconstruction. This is crucial for the primary and secondary prevention, too.
\end{abstract}

Keywords: Conservative treatment; neuromuscular rehabilitation; torn anterior cruciate ligament.

Anterior cruciate ligament (ACL) injuries are common and the economic burden of these injuries is high. ${ }^{[1,2]}$ However, the optimal management of a torn ACL of the knee is still controversial. ${ }^{[3]}$

Furthermore, there is still controversy in regards to the number of bundles. It is widely accepted that the human ACL is composed of two bundles: the anteromedial (AM) and posterolateral (PL). On the other hand, there are recent reports demonstrating a third bundle intermediate (IM), or up to 10 bundles..$^{[4,5]}$

This fact may be one of the reasons which the double bundle technique compared to the single bundle is not more effective in preventing osteoarthritis and does not produce a more favorable failure rate. ${ }^{[6]}$

Another fact is that dynamic knee stability is not affected by only passive (ligamentous) joint restraints,
$\ddot{O Z Z}$

Ön çapraz bağ (ÖÇB) yaralanmaları yaygındır ve bu yaralanmaların ekonomik yükü fazladır. Ancak, dizde ÖÇB yırtıklarının optimal tedavisi halen tartışmalıdır. Ön çapraz bağ cerrahisi her hasta için uygun değildir; bazı hastalarda çok sıkı bir nöromusküler rehabilitasyon programı ile cerrahi olmayan tedavi endikasyonu vardır. Nöromusküler rehabilitasyon, ÖÇB onarımı öncesi de gereklidir. $\mathrm{Bu}$, primer ve sekonder korunma için de hayati önem taşır.

Anahtar sözcükler: Konservatif tedavi; nöromusküler rehabilitasyon; ön çapraz bağ yırtığı.

but also by active (neuromuscular) joint restraints. Neuromuscular control deficit during dynamic movements has been hypothesized to be the primary cause for both primary and secondary ACL injuries (re-injury following ACL reconstruction), creating excessive joint loads and leading to detrimental ACL stress/strains and failure, eventually. ${ }^{[7]}$

Moreover, some patients may have the potential to heal their ACL rupture without need of surgery. For instance, in a recent study, the spontaneous healing of the complete ACL rupture persisted in 12 patients without using an extension brace and they were able to continue with their athletic activity. ${ }^{[8]}$

Reconstruction of the ACL is not a prerequisite for restoring the muscle function; however, restoring muscle function is a prerequisite for conservative or surgical treatment of the torn ACL. ${ }^{[9,10]}$

\footnotetext{
- Received: May 18, 2015 Accepted: June 27, 2015
}

- Correspondence: O. Şahap Atik, MD. Gazi Üniversitesi Tıp Fakültesi Ortopedi ve Travmatoloji Anabilim Dalı, 06500 Beşevler, Ankara, Turkey. Tel: +90 312 - 2025528 Fax: +90 312 - 2129008 e-mail: satikmd@gmail.com 
In a prospective, longitudinal study of nonreconstructed patients, activity level and subjective knee function 15 years after ACL injury were within acceptable limits with neuromuscular rehabilitation plus lifestyle changes. ${ }^{[1]}$ In the majority of nonreconstructed patients, early activity modification and neuromuscular rehabilitation resulted in a good knee function and an acceptable activity level. Reduced activity level of the patients engaged in contact sports at the time of injury affected their quality of life more than those involving in noncontact sports. ${ }^{[11]}$

Another prospective cohort study for the prevalence of tibiofemoral osteoarthritis 15 years after non-surgical treatment of ACL injury had a favorable long-term outcome regarding incidence of radiographic knee OA, knee function and symptoms, and need for ACL reconstruction. ${ }^{[12]}$ Early activity modification and neuromuscular knee rehabilitation appeared to be related to the low prevalence of radiographic knee OA. The authors concluded that initial treatment without ACL reconstruction should be considered in patients with ACL injury with moderate activity level to avoid possible re-injuries. ${ }^{[12]}$

Frobell et al. ${ }^{[10]}$ reported that in young and active adults with acute ACL tears, a strategy of rehabilitation plus early ACL reconstruction was not superior to a strategy of rehabilitation plus optional delayed ACL reconstruction. The latter strategy substantially reduced the frequency of surgical reconstructions. ${ }^{[10]}$ Anterior cruciate ligamentinjured patients following a non-surgical treatment course, including recommendations of activity modifications, and operatively treated patients did not have significantly different rates of returning to pivoting sports after one year in another pairmatched cohort study. ${ }^{[13]}$

\section{Conclusion}

As suggested by Lars Engebretsen, "ACL surgery is not suitable for all patients, nor for all surgeons. Thus, we need to use the knowledge we have and implement the primary and secondary prevention programs". ${ }^{[14]}$

Although the majority of ACL reconstruction surgeries can successfully restore the mechanical stability of the injured knee, postsurgical outcomes remain widely varied. Less than half of athletes undergoing ACL reconstruction return to sport within the first year after surgery, while approximately 1 in 4 to 1 in 5 young and active athletes undergoing ACL reconstruction will go on to a second knee injury. ${ }^{[15]}$ Reduced neuromuscular control and high- risk movement biomechanics, which appear to be heavily influenced by abnormal trunk and lower limb movement patterns, not only predict the first knee injury risk, but also predict the re-injury risk.

In conclusion;

- There are some indications for non-surgical treatment with a strict neuromuscular rehabilitation program.

- Neuromuscular rehabilitation is also necessary prior to ACL reconstruction.

- This is crucial for the primary and secondary prevention, too.

\section{Declaration of conflicting interests}

The authors declared no conflicts of interest with respect to the authorship and/or publication of this article.

\section{Funding}

The authors received no financial support for the research and/or authorship of this article.

\section{REFERENCES}

1. Öztürk S, Kılıç D. What is the economic burden of sports injuries? Eklem Hastalik Cerrahisi 2013;24:108-11.

2. Mather RC 3rd, Koenig L, Kocher MS, Dall TM, Gallo P, Scott DJ, et al. Societal and economic impact of anterior cruciate ligament tears. J Bone Joint Surg [Am] 2013;95:1751-9.

3. Atik OŞ. Do we know the optimal management of a torn anterior cruciate ligament of the knee? Eklem Hastalik Cerrahisi 2014;25:63.

4. Otsubo H, Shino K, Suzuki D, Kamiya T, Suzuki T, Watanabe $\mathrm{K}$, et al. The arrangement and the attachment areas of three ACL bundles. Knee Surg Sports Traumatol Arthrosc 2012;20:127-34.

5. Mommersteeg TJ, Kooloos JG, Blankevoort L, Kauer JM, Huiskes R, Roeling FQ. The fibre bundle anatomy of human cruciate ligaments. J Anat 1995;187:461-71.

6. Song EK, Seon JK, Yim JH, Woo SH, Seo HY, Lee KB. Progression of osteoarthritis after double- and singlebundle anterior cruciate ligament reconstruction. Am J Sports Med 2013;41:2340-6.

7. Hewett TE, Di Stasi SL, Myer GD. Current concepts for injury prevention in athletes after anterior cruciate ligament reconstruction. Am J Sports Med 2013;41:216-24.

8. Costa-Paz M, Ayerza MA, Tanoira I, Astoul J, Muscolo DL. Spontaneous healing in complete ACL ruptures: a clinical and MRI study. Clin Orthop Relat Res 2012;470:979-85.

9. Atik OS. Is reconstruction of the anterior cruciate ligament a prerequisite for restoring muscle function? Eklem Hastalik Cerrahisi 2009;20:125-6.

10. Frobell RB, Roos EM, Roos HP, Ranstam J, Lohmander LS. A randomized trial of treatment for acute anterior cruciate ligament tears. N Engl J Med 2010;363:331-42.

11. Kostogiannis I, Ageberg E, Neuman P, Dahlberg L, Fridén $\mathrm{T}$, Roos H. Activity level and subjective knee function 15 
years after anterior cruciate ligament injury: a prospective, longitudinal study of nonreconstructed patients. Am J Sports Med 2007;35:1135-43.

12. Neuman P, Englund M, Kostogiannis I, Fridén T, Roos H, Dahlberg LE. Prevalence of tibiofemoral osteoarthritis 15 years after nonoperative treatment of anterior cruciate ligament injury: a prospective cohort study. Am J Sports Med 2008;36:1717-25.

13. Grindem H, Eitzen I, Moksnes H, Snyder-Mackler L,
Risberg MA. A pair-matched comparison of return to pivoting sports at 1 year in anterior cruciate ligamentinjured patients after a nonoperative versus an operative treatment course. Am J Sports Med 2012;40:2509-16.

14. Engebretsen L. ACL surgery is not for all patients, nor for all surgeons. Knee Surg Sports Traumatol Arthrosc 2014;22:1-2.

15. Hewett TE, Di Stasi SL, Myer GD. Current concepts for injury prevention in athletes after anterior cruciate ligament reconstruction. Am J Sports Med 2013;41:216-24. 